\title{
POLEMIK KEADILAN SAHABAT DALAM PERIWAYATAN HADIS
}

\author{
Fuad Faqih \\ Institut Agama Islam Bani Fattah Jombang, Indonesia \\ fuadd678@gmail.com
}

\begin{abstract}
Abstrak: Hadis sebagai salah satu sumber shari'at dalam Islam disamping al-Qur'an. Selain mempunyai fungsi sebagaimana penulis ungkapkan di atas juga sebagai penjelas dan penguat firman Allah (al-Qur'an). Dalam perjalanannya hadis tidak semulus al-Qur'an yang sudah diakui keotentikannya -karena mutawätir secara lafad dan ma'na-, adanya larangan Nabi terhadap penulisan hadis yang dikawatirkan teks al-Qur'an akan bercampur dengan teks hadis, adapun hadis sendiri baru dikodifikasi atau dibukukan pada akhir abad pertama atau pada awal abad kedua hijriyah pada masa khalifah Umar bin Abdul Aziz. Disinilah peran sahabat dalam mengungkapkan dan juga sebagai penyambung perkataan-perkataan (baca: hadis) Nabi.

Adanya persepsi bahwa para sahabat kullubum 'adū nampaknya telah menjadikan sahabat sebagai bahan kajian yang sangat dominan dalam menentukan kapabilitas dan kwalitas hadis, ada yang pro dan juga ada yang kontra dengan keadilan seluruh sahabat.
\end{abstract}

Kata Kunci: Keadilan, Sahabat, Riwayat Hadis 


\section{Pendahuluan}

Nabi Muhammad Saw adalah sosok rasul dan figur utama bagi ummat Islam, seorang pemimpin central, menjadi hakim dan sekaligus sebagai sumber rujukan bagi para sahabat ketika itu. Maka segala persoalan dan problematika yang timbul dikalangan sahabat semuanya merujuk kepada beliau. Ketika Rasulullah Saw wafat, tongkat estafet da'wah berpindah ketangan para sahabat. Dari merekalah umumnya kita mengenal Islam baik itu al-Qur'an maupun Sunnah Rasulullah Saw.

Sahabat sebagai tokoh yang berperan penting terhadap sumber rujukan dalam Islam, memiliki tempat yang strategis dalam kajian keislaman, hal ini menjadi wajar mengingat dalam posisi merekalah sampai detik ini kita masih bisa melihat bukti-bukti sejarah, lebih dari itu kita dapat memahami hadits yang memang berasal dari periwayatan mereka. Namun demikian, sejalan dengan perkembangannya sahabat tidak lagi hanya ditempatkan pada posisinya yang mulia namun sebaliknya.

Para sahabat, dalam menerima hadis dari Rasulullah saw. Adakalanya secara langsung dan adakalanya melalui para sahabat lain. Mereka tidak enggan mengambil hadis dari sesamanya dan menisbatkannya kepada Rasulullah SAW. Tanpa menyebut atau menunjukkan sahabat yang menjadi perantara periwayatan. Penyebutan seperti itu bisa dikatakan sangat jarang sekali. Para ulama hadis telah melakukan peneitian terhadap hadis-hadis jenis seperti itu dan berkenan menerimanya, yakni hadis-hadis mursal sahabat. Dengan alasan, para sahabat adalah orang-orang yang adil dan tidak diduga kuat melakukan pendustaan atas diri Rasulullah saw.

Adanya berbagai persepsi tentang keseluruhan sahabat adalah adil, nampaknya telah menjadikan sahabat sebagai bahan kajian yang sangat dominan dalam menentukan kapabilitas dan kwalitas hadist. Berkaitan dengan hal tersebut, maka, penulisan makalah ini adalah dalam rangka merespon berbagai persepsi tersebut guna memperoleh gambaran utuh tentang sahabat yang memang dari merekalah hadist diriwayatkan. Mengingat bahwasannya al-Qur'an dan Hadist merupakan sumber utama dalam kajian ke-Islaman, maka kajian akan sahabat sebagai tokoh pemeran penyampai hadits menjadi sangat sentral dan bahkan vital.

Sahabat memang dikenal sangat antusias mendengarkan hadis Rasul saw. Secara langsung atau merekam tindakan beliau. Dan riwayat seperti itulah yang memiliki kekuatan hafalan tiada tara. Namun demikian, terkadang ada seorang sahabat yang mendengar suatu hadis Nabi SAW dari sahabat lain, tetapi mendiamkannya, karena dia pandang tidak sejalan dengan hadis lain atau dengan pemahamannya terhadap alqur'an. Dari sinilah muncul dua sikap dikalangan mereka. Pertama, sikap 
diam, tanpa komentar dan tanpa menerimanya. Kedua, mengingkarinya dan bahkan mengkritiknya, karena dinilai sebagai kesalahan atau kekeliruan dari sahabat yang bersangkutan.

Dalam makalah ini, penulis berusaha memaparkan siapa sebenarnya yang dimaksud sebagai sahabat Nabi SAW, apakah "benar" semua sahabat itu adil, dan juga nama-nama sahabat perawi hadis beserta jumlah hadis yang diriwayatkannya.

\section{Pembahasan}

\section{Konsep Sahabat}

Secara bahasa kata sahabat berasal dari bahasa arab yaitu sabibayashabu, sahabatan, săhibun, artinya ; sahabat, teman bergaul dan duduk. Dalam al-Qur'an kata sahabat banyak sekali terdapat dalam al-Qur'an, jika diamati di dalam al-Qur'an terdapat banyak kata yang berbunyi ; tusăbibni, săhibabumā, șăbibabu, șăbibatabu, ashäbun. Kata ni tedapat dalam al-Qur'an sebanyak 97 kali.

Adapun pengertian sahabat adalah sebagai berikut:

1. Ibn Hajar al-Aṣqālani dalam kitabnya menyatakan bahwa sahabat adalah orang yang bertemu dengan Rasulullah saw, beriman kepadanya dan meninggal dalam keadaan Islam. ${ }^{1}$ Dalam pandangannya ia menyatakan bahwa yang dapat di anggap sebagai sahabat adalah mereka yang memenuhi kriteria di bawah ini ;

a. Bertemu dengan Nabi saw dan menerima dakwahnya, dalam waktu lama atau sebentar.

b. Meriwayatkan hadis dari Nabi SAW ataupun tidak.

c. Ikut berperang bersama Nabi SAW ataupun tidak.

d. Sempat melihat Nabi saw, sekalipun tidak pernah duduk menemani atau tidak pernah melihat Nabi karena sebab tertentu (seperti orang buta).

2. Menurut ulama hadits, sahabat adalah setiap muslim yang pernah melihat Rasulullah Saw. ${ }^{2}$ Imam Bukhari dalam kitab Shahihnya mengatakan "Barang siapa dari kaum muslimin yang berteman atau melihat nabi, maka dapat dikatakan sebagai sahabat beliau". Dan Imam Ahmad menyebutkan tentang kriteria sahabat, yaitu

\footnotetext{
${ }^{1}$ Ibn Hajar al-Asqālani, Al-Ișābah fi Tamyīẓi al-Ṣāhabah, (Darr al-kutub al-Azhar, Mesir: 1853), jilid 1, hal. 4

2 'Ajjàj al-Khotīb, Ușūl al-Hadìs 'Ulümubu wa Mustolāhubu (Dar al-fikr, Beirut : 2008)hal. 255.
} 
mereka yang mengikuti perang Badar, yang menemani beliau walau hanya setahun atau sebulan atau sehari atau bahkan sesaat. ${ }^{3}$

3. Ada pula ulama yang menyebutkan sahabat tidak hanya pada mereka yang berteman dengan nabi dan melihat beliau, akan tetapi mensyaratkan keikutsertaan dalam meriwayatkan walau hanya satu atau dua hadis saja. ${ }^{4}$

4. Mahmud at-Thahan dalam kitabnya taysir mustaläbu al-hadis menyebutkan pengertian sahabat, yaitu orang muslim yang bertemu dengan nabi dan ia meninggal dalam keadaan beragama Islam. $^{5}$

5. Menurut Ibn Hazm, sahabat adalah setiap orang yang pernah ikut dalam majlis nabi walaupun hanya sesaat, mendengar dari beliau walaupun hanya satu kata, menyaksikan beliau dalam menangani satu masalah dan tidak termasuk orang-orang yang munafik yang kemunafikannya berlanjut sampai populer dan meninggal seperti itu. $^{6}$

6. Sedangkan yang dimaksud sahabat dalam pandangan ulama uṣul fiqh adalah mereka yang lama persahabatannya dengan Nabi saw dan berada dalam suatu masa. ${ }^{7} \mathrm{Hal}$ ini menunjukkan bahwa sahabat dalam pandangan usüliyyin diartikan bagi kaum yang dikenal dengan lamanya berdiam bersama Nabi dan keikutsertaannya dalam perjalanan Nabi saw dan juga berperang bersama Nabi saw. ${ }^{8}$ Pendapat ini bertentangan dengan istilah yang masyhur menurut ahli hadits, yaitu bahwa sahabat ialah orang yang bertemu Nabi saw dan mati dalam keadaan Islam.

7. Disisi lain masih ada ulama yang memasukkan malaikat sebagai sahabat, seperti pendapat Syaikh Taqiyuddin, namun demikian pendapat ini tergolong minoritas. Sebagaimana diungkapkan oleh al-Razy dalam kitabnya Asräru al-Tanzill, bahwa Nabi saw tidak di utus untuk malaikat. ${ }^{9}$

3 'Ajjāj al-Khoțib, al-Sunnah Qobla al-Tadwīn (ummu al-quro, Kairo : 1988)hal. 387.

4 'Ajjaj al-Khotib, Ușül al-Hadìs 'Ulümubu wa Mustolāhubu (Dar al-fikr, Beirut : 2008)hal. 256.

5 Mahmūd at-Tahan, Taysìru Mustalābi al-Hadis (Markaz al-Hadyi li al-Dirasat, Iskandariah : $1415 \mathrm{H}$ ) hal. 152.

6 'Ajjaj al-Khotib, Ușul al-Hadis 'Ulumubu wa Mustolāhubu (Dar al-fikr, Beirut : 2008)hal.255.

${ }^{7}$ Ibid. Hal. 258.

${ }^{8}$ Pendapat ini mirip dengan pengertian sahabat yang dikemukakan oleh Anas bin Malik dan Sa'id bin Musaib.

${ }^{9}$ al-Rāzy, Asräru al-Tanzìl,(Darr al-Fikr, Beirut : tth), hal. 34 
Kata sahabat menurut bahasa jamak dari sahib artinya yang menyertai. Menurut para ulama yang disebut "sahabat" adalah orang yang bertemu dengan Nabi SAW dalam keadaan beriman dan meninggal dunia sebagai pemeluk Islam. Jadi, orang yang bertemu dengan Nabi sedang dia belum memeluk agama Islam, tidaklah dipandang sahabat. Sebaliknya orang yang hidup pada masa Nabi dan memeluk Islam tapi hingga sahabat itu wafat tidak bertemu Nabi tidak pula disebut sahabat tetapi disebut muhadhramun. Akan tetapi, ada orang yang hidup pada masa Nabi dan beriman kepadanya tetapi menjumpai Nabi setelah beliau wafat, seperti Najasi dan Abu Dzu'aib, yang pergi dari rumahnya setelah ia beriman untuk menjumpai Nabi di Madinah. Setiba di Madinah, Nabi telah wafat. Baik Najasi dan Abu Dzu'aib, mereka berdua termasuk sahabat Nabi.

Demikian pengertian sahabat yang dapat penulis paparkan, namun berdasarkan apa yang telah penulis sampaikan di atas secara umum bisa dikatakan bahwa mereka yang dapat disebut sebagai sahabat adalah mereka yang pernah bertemu dengan Nabi dan beriman kepadanya.

\section{Ṭabāqōt (tingkatan) Sahabat}

Orang yang meriwayatkan hadis meskipun hanya satu hadis atau kalimat dari Nabi SAW dapat dikatakan sebagai sahabat, atau juga ia disebut sahabat melalui sahabat lain yang mengatakan bahwa ia adalah seorang sahabat, ini semua menunjukkan kumuliaan kedudukan Nabi SAW, dan juga para sahabat mempunyai tingkatan-tingkatan yang berbeda, maka ada para al-sābiqūn al-awwalū. Mereka yang lama persahabatannya dengan Nabi saw, yang mengorbankan segenap harta dan jiwanya untuk da'wah, dan juga ada sahabat yang hanya melihat sekali saja ketika haji wada', maka tidak logis jika semua sahabat berada dalam satu tingkatan saja.

'Ajjaj al-Khațib dalam kitabnya Al-sunnah qobla al-tadwin menyebutkan tingkatan-tingkatan sahabat sebagai berikut:

1. Orang yang pertama masuk Islam di Mekkah, seperti al-khulafa, al-rāshidūn.

2. Para sahabat yang masuk Islam sebelum para penduduk Mekkah bermusyawarah di dar al-nudwah.

3. Para sahabat yang ikut berhijrah ke Habasyah.

4. Mereka yang ikut dalam perjanjian 'aqōbab 1 .

5. Mereka yang likut dalam perjanjian 'aqōbah 2, kebanyakan dari mereka ini adalah dari golongan Ansor.

6. Orang yang mula-mula ikut hijrah bersama nabi, dan shalat di Quba, sebelum masuk kota Madinah. 
7. Para sahabat yang ikut dalam perang Badar.

8. Orang yang berhijrah antara perang Badar dan perjanjian Hudaibiyah.

9. Para sahabat yang ikut serta Bai'at Ridlwän dalam perang Hudaibiyah.

10. Orang yang berhijrah antara Hudaibiyah dan fathu makkah, seperti Khalid bin Walid, Amru bin Ash, dan Abu Hurairah.

11. Orang yang masuk Islam ketika fathu makkah.

12. Dan anak-anak yang melihat Nabi saw ketika fathu makkah dan haji wada'.

Pembagian sahabat menjadi beberapa tingkat merupakan kenyataan dari adanya perbedaan tingkat keistimewaan masing-masing di antara masyarakat muslim pengikut Rasulullah SAW. Adalah tidak adil rasanya apabila orang yang pertama masuk Islam disamakan tingkatannya dengan mereka yang masuk Islam belakangan apalagi dalam keadaan terpaksa.

\section{Keadilan Sahabat}

Ketetapan keadilan seluruh sahabat adalah tentu bukan tanpa alasan, karena itu sangat penting dan dibutuhkan, karena mereka adalah para penukil syari'at dari rasulullah SAW, apabila kita meragukan keadilan mereka, maka secara tidak langsung kita mematikan sumbersumber syari'at agama, dari sisi lain kita telah mendustakan ayat-ayat alQur'an dan Hadis yang menetapkan keadilan bagi mereka. ${ }^{11}$

Bagi umat Islam, sahabat Nabi menduduki posisi yang sangat menentukan dalam Islam. Mereka menjadi jalur yang tak terhindarkan antara Nabi dan generasi berikutnya. Merekalah yang secara langsung melihat dan mengalami bagaimana nabi mengaplikasikan wahyu. Dengan kata lain, mereka adalah agen tunggal, atau dari diri merekalah Alquran dan Sunnah Nabi dapat diketahui. Para sahabat adalah generasi Islam pertama yang menerima didikan langsung dari Nabi Muhammad saw. Atas dasar ini, maka mayoritas ulama menganggap semua sahabat adalah adil ('udul), yakni bahwa semua sahabat Nabi terbebas dari penyebaran hadis palsu secara sengaja. Oleh karena itu, para ulama akan menerima kesaksian sahabat mengenai hal-hal yang menyangkut hadis Nabi. Imbasnya, jati diri seorang sahabat terbebas dari objek penelitian.

Para ulama Hadis bersepakat bahwa seluruh sahabat adalah orang yang adil, baik itu secara ijmäli (umum) maupun tafsìli (terperinci). Tidak

\footnotetext{
10 'Ajjaj al-Khoțib, al-Sunnah Qobla al-Tadwin (Ummu al-Quro, Kairo : 1988)hal. 391-392.

11 Muhammad Tōohir al-Jawwābi, Al-jarb wa al-ta'dìl baina al-mutashaddidīn wa almutasabilin (Ad-dar al-'arabiyah : 1997)hal. 32.
} 
ada yang berselisih pendapat tentang hal ini, tidak ada yang menuduh mereka berdusta apalagi memalsukan Hadis, kecuali segelintir orang yang di sebutnya ahli bid'ah-, maka wajib bagi muslimin untuk meyakini sikap sahabat tersebut. Akan tetapi para ulama akan tetapi membahas jarh dan ta'dīl kepada periode setelah mereka ${ }^{12}$.

Pernyataan diatas didasarkan bahwa keadilan sahabat telah ditetapkan Allah swt melalui penjelasan tentang kesuciannya, dan mereka adalah orang-orang pilihan Allah SWT. hal ini didasarkan pada dalil alQur'an berikut;

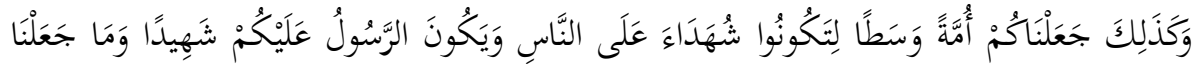

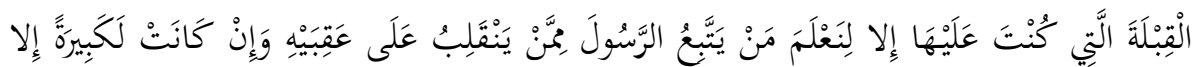

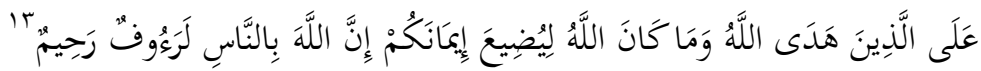

Dan demikian (pula) Kami telah menjadikan kamu (umat Islam), umat yang adil dan pilihan agar kamu menjadi saksi atas (perbuatan) manusia dan agar Rasul (Mubammad) menjadi saksi atas (perbuatan) kamu. Dan Kami tidak menetapkan kiblat yang menjadi kiblatmu (sekarang) melainkan agar Kami mengetahui (supaya nyata) siapa yang mengikuti Rasul dan siapa yang membelot. Dan sunggub (pemindahan kiblat) itu terasa amat berat, kecuali bagi orang-orang yang telah diberi petunjuk oleh Allab; dan Allah tidak akan menyianyiakan imanmu. Sesunggubnya Allah Maba Pengasib lagi Maba Penyayang kepada manusia.

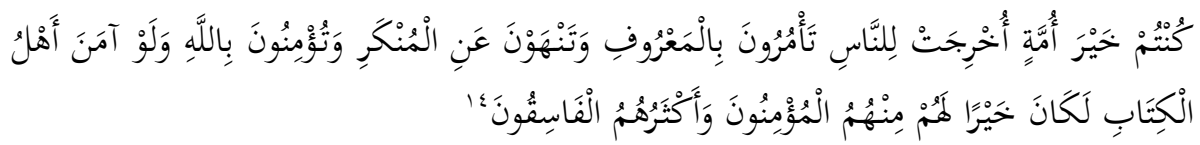

Kamu adalah umat yang terbaik yang dilabirkan untuk manusia, menyurub kepada yang ma'ruf, dan mencegah dari yang munkar,dan beriman kepada Allah. Sekiranya Abli Kitab beriman, tentulab itu lebih baik bagi mereka, di antara mereka yang beriman, dan kebanyakan mereka adalah orang-orang yang fasik.

Inilah dalil yang dijadikan landasan bagi golongan ahlussunnah, sehingga ada pernyataan bahwa semua sahabat itu adil, yang dimaksud dengan adilnya sahabat ialah sebagaimana yang dimaksud dalam arti

12 Mustafa al-Sibā'I, Al-Sunnah Wa Makānatubā Fi Al-Tasyrì' Al-Islämi (al-Maktab alIslämiy, Kairo, 2000) hal. 290.

${ }^{13}$ Q.S.Al-Baqarah : 143.

${ }^{14}$ Q.S.Ali Imron :110. 
keadilan sahabat itu sendiri; yakni setiap orang yang sezaman dengan Nabi SAW; dilahirkan pada zaman Nabi SAW, tidak pernah berdusta atau menipu, dan -karena itu- tidak diperbolehkan untuk menyakitinya meskipun ia telah berbuat yang tercela. sebenarnya apa rahasia yang terdapat dibalik sikap ahlusunah ini. Mereka berdalil : Rasulullah adalah haq, al-Qur'an adalah haq, apa yang dibawa oleh Nabi SAW adalah haq, dan yang menyampaikan -ajaran Nabi- itu semua kepada kita adalah para sahabat. Maka barangsiapa yang melemahkan sahabat sebenarya mereka ingin melemahkan al-Qur'an dan al-Sunnah. Karena merekalah sebenarnya yang perlu untuk diberlakukan al-jarb dan mereka adalah kafir. ${ }^{15}$

Akan tetapi ada juga yang tidak sependapat dengan ablusunnah dalam keadilan sahabat, seperti halnya Syi'ah, Khawarij, dan lain-lain. Golongan Syi'ah, pada dasarnya tidak jauh berbeda dengan golongan ablussunah dalam hal kriteria tentang sahabat, yakni setiap orang yang bertemu dengan Nabi saw dan beriman kepadanya serta meninggal dalam keadaan Islam. Akan tetapi dalam hal keadilan sahabat mereka berbeda pendapat dengan ablussunnah. Dalam pandangan Syi'ah sahabat tidak semuanya bisa dikatakan adil, mereka hanya mau bersandar kepada Hadis yang diriwayatkan oleh para ablu bait. $^{16}$.

Namun demikian ada juga pendapat Syi'ah yang menyatakan bahwa sahabat yang adil adalah mereka yang ikut berjuang bersama Ali ra serta mengakui kewaliannya. Pendapat ini mereka sandarkan pada alasan bahwa Ali RA adalah orang pertama yang masuk Islam, Ia juga wali Allah swt, saudara Nabi SAW dan berada dalam asuhannya sejak masih kecil, ayah dari cucu Nabi, suami perempuan suci, panglima perang melawan kemusyrikan, panglima pasukan muslim, pembunuh musuh Islam, orang yang paling jujur dan mampu membedakan yang baik dan buruk, putra Abu Thalib -paman dan pelindung Nabi SAW-.

Seperti halnya Syi'ah, Khawarij juga berbeda pendapat dengan ablusunnah, Al-Siba'i mengatakan : (bahwasanya para Khawarij pada mulanya menetapkan keadilan bagi seluruh sahabat sebelum terjadinya fitnah, akan tetapi kemudian mengkafirkan Ali, Utsman, orang-orang yang ikut berperan dalam perang Jamal, dan membenarkan peristiwa altabkim. Dengan peristiwa tersebut, mereka menolak Hadis-hadis jumbür

${ }^{15}$ Ibn Hajar al-Asqālani, Al-Ișābah fi Tamyìz al-Ṣahābah, (Darr al-kutub al-Azhar, Mesir: 1853), jilid 1.hal. 7.

${ }^{16}$ Mustafă al-A'dhāmi, Dirāāàt fi al-Hadis al-Nabawì wa Tärikehi Tadwinihi (al-Maktab alIslāmi, Beirut, 1980) hal. 25. 
sahabat setelah terjadinya fitnah tersebut ${ }^{17}$. Adapun Mu'tazilah, mereka menolak semua Hadis sahabat ${ }^{18}$.

Untuk mengarahkan pembahasan pada tulisan ini, pertanyaan yang patut diketengahkan, apakah keadilan para sahabat telah berlangsung sejak seorang sahabat menyatakan diri menjadi muslim, atau keadilan dalam masa pembentukan tasyri' belum berlaku predikat itu, mengingat para sahabat masih sering melalukan pelanggaran. Kasus perilaku menyimpang dilaporkan juga terjadi dalam hal relasi gender antara para sahabat yang berjenis kelamin laki-laki dengan sahabat Nabi yang berjenis kelamin perempuan. Perilaku menyimpang itu banyak yang diselesaikan Nabi saw. dengan diturunkannya Alquran melalui asbab alnu₹ul ayat atau melalui hadis Nabi melalui asbab al-wurud al-hadis). Faktafakta relasi gender menyimpang pada masa Nabi masih hidup antara lain:

Kasus laki-laki yang mengaku sebagai utusan Nabi yang membolehkan dirinya bermalam di rumah mana saja yang ada anak gadis yang dia sukai. ${ }^{19}$ Laki-laki yang mencabuli isteri tetangganya. ${ }^{20}$ Seorang yang ingin mengobati seorang perempuan tetapi dicabulinya. ${ }^{21}$ Laki-laki yang sengaja mencium seorang perempuan di pasar. $^{22}$

Kasus Nabhan al-Tammar penjual kurma yang mendekap dan mencium seorang perempuan cantik di pasar. ${ }^{23}$ Kasus Khawwat bin Jubair bin Nu'man yang asyik bercengkarama dengan perempuan dalam sebuah perang. ${ }^{24}$ Himnah bin Jahsy mengaku pernah sedang haid tapi digauli suaminya. ${ }^{25}$ Himnah pernah menikah dengan Mus'ab bin 'Umair, atau Thalhah bin 'Ubaidillah. Kasus Umar bin alKhaththab juga mengaku pernah yang lebih aib lagi. ${ }^{26}$ Umar pernah menggoda dan

\footnotetext{
${ }^{17}$ Musțafa al-A'dhāmi, Dirasät fi al-Hadis al-Nabawi wa Tarikhi Tadwinihi (al-Maktab alIslāmi, Beirut, 1980) hal. 22.

${ }^{18}$ Pendapat ini diungkapkan oleh Syaikh al-Khudri dan al-Siba'i, untuk lebih jelasnya baca: Musthafa al-A'dhāmi, Diräsat fi al-Hadis al-Nabawì wa Tärikhi Tadwinibi (alMaktab al-Islāmi, Beirut, 1980) hal. 23.

${ }^{19}$ Lihat al-Thabrani, Mu'jam al-Kabir, juz XX, h. 100; Mu'jam al- Awsat, juz V, h.

131.Abd al-Razzaq, Mushannif, juz XI, h. 261

${ }^{20}$ Lihat Al-Suyuthi, Durr al-Mantsur, Jilid V, h. 351. Muslim, Shabih Muslim, Juz IV, 2115.

${ }^{21}$ Lihat Al-Bukhariy, Tafsir Surah Hud ayat 114. Muslim, Shabih Muslim, juz VIII, h. 101.

${ }^{22}$ Lihat Ibn Hamzah, al-Bayan wa al-Ta'rif fi Asbab al-Nuzul al-Hadits al-Syarif, Jilid I, Mesir: Maktabah al-Mishr, 1985, h. 16. Al-Hakim, Mustadrak, kitab al-budud, jilid IV, h. 418.

${ }^{23}$ Al-Thabrani, Ibn Atsir, Usud al-Ghabah, jilid I, h. 324.

24 Abu Dawud, Sunan Abu Dawud, kitab al-thaharah, hadis no. 266, Jilid I, h. 83.

25 Al-Darimiy, Sunan al-Darimiy, kitab al-thaharah, hadis no. 1090, jilid I, h. 255.

${ }^{26}$ Ibn Katsir, Tafsir Ibn Katsir, jilid I, h. 182. Ahmad bin Hanbal, kitab hadis no. 2569.
} 
mencium isterinya saat berpuasa. ${ }^{27}$ Jabir ingin menikahi seorang perempuan hanya karena melihat tubuhnya. ${ }^{28}$ Zubair bin Awwam pernah tergoda kepada Zainab, saudara sesusuan anaknya. ${ }^{29}$

Fakta-fakta kasus tersebut menunjukkan bahwa masyarakat Madinah dan para sahabat sekalipun berada di tengah-tengah Nabi Muhammad saw. dan mereka telah memeluk serta setia kepada Islam, tetap memiliki hubungan laki-laki dan perempuan yang bergejolak.

Lalu apakah keadilan para sahabat itu berlaku secara umum, termasuk perempuan? karena secara individu ada sahabat Nabi laki-laki kerap kali melakukan relasi gender yang menyimpang yang melibatkan perempuan. Ataukah keadilan para sahabat itu nanti berlaku setelah mereka telah matang benar imannya, atau justru setelah Nabi Muhammad saw. tidak berada lagi ditengah-tengah mereka? Mengingat pada masa pertengahan kenabian, atau sepeninggalan Nabi Muhammad masih ada pula para sahabat yang melakukan kekeliruan yang mencoreng kredibiltas mereka sebagai generasi terbaik, atau terlibat dalam beberapa affair gender menyimpang, begitu pula keterlibatan mereka dalam berbagai kasus politik.

Dari hasil penelitian menunjukkan bahwa, sekalipun para sahabat telah dijamin keadilannya, akan tetapi tetap secara perorangan tidak boleh diberlakukan secara menyeluruh.. Pada awalawal pembentukan tasyri' keadilan itu belum berlaku mengingat banyak kasus-kasus yang terjadi melibatkan para sahabat yang justru menjadi asbab al-nuzul ayat atau asbab al-wurud hadis. Karena kendatipun mereka yang telah hidup bersama Nabi saw. sering bertemu dengan Nabi saw. dan masuk Islam, namun berdasarkan fakta yang dibahas menunjukkan masih ada individuindividu di kalangan sahabat yang tidak memiliki kualitas keagamaan dan kualitas sosial yang baik. Salah satu aspek yang sering mengganggu integritas pribadi dan spiritual para sahabat yaitu dalam persoalan pengendalian diri dari pengaruh hawa nafsu misalnya dalam relasi gender. Dalam kaitannya dengan relasi gender baik pada awal-awal pembentukan tasyri' atau pertengahan bahkan setelah Nabi Muhammad saw. mangkat banyak para sahabat yang terbukti tidak dapat menguasai pengaruh biologis sebagai manusia laki-laki dan perempuan dari godaan nafsu syahwat.

Tapi dalam hubungan pertobatan dan menyadari kekeliruan para sahabat selalu spontan melakukannya, untuk itu di antara mereka banyak yang langsung mengakui kesalahan di hadapan Rasulullah saw. Yang

\footnotetext{
27 Abu Dawud, kitab al-shaum, hadis no. 2037

28 Abu Dawud, kitab al-nikah, hadis no. 1783

${ }^{29}$ Al-Syafi'iy, Musnad al-Syafi'iy, juz III, h. 17
} 
menarik adalah di antara para sahabat yang tiba-tiba merasa dirinya melakukan kesalahan, mereka segera melaporkan pelanggarannya itu, untuk memintakan penyelesaian hukum. Kemudian, Nabi kadang menyelesaian secara langsung atau beliau menunggu ketetapan hukumnya dari Allah swt. Adapun kasus yang terjadi sesudah Nabi diselesaikan berdasarkan ketentuan Alquran atau Hadis.

Kendatipun para sahabat banyak yang belum dapat mengendalikan pengaruh nafsu syahwat dirinya, namun menyangkut dengan segala yang berkaitan dengan kesetiaan dan kedustaan dengan mengatasnamakan Rasulullah saw. tidak terbukti mereka lakukan kecuali ada seorang sahabat yang telah ceroboh melakukannya, akibatnya dia mendapat hukuman berat. Kasus yang dimaksudkan, yaitu seorang sahabat yang mengaku utusan Nabi untuk melamar anak gadis yang disukainya. Ketika kasus itu disampaikan kepada Nabi Muhammad, maka beliau menyuruh Ali dan al-Zubair membunuh dan membakar jasad orang tersebut.

Dengan demikian, keadilan para sahabat memang mendapat jaminan dari Nabi Muhammad saw. sebagai generasi terbaik. Keadilan para sahabat dimaksud hanya berkenaan dengan berita-berita yang berasal dari Nabi Muhammad, sementara dalam hubungan sebagai pribadi dan manusia biasa masih sering terjadi pelanggaran dalam pengendalian diri. Oleh karena itu, secara umum para sahabat adalah adil, tetapi tidak boleh menutup kemungkinan untuk mengkritisi kehidupan pribadi mereka. Bila hanya berkaitan dengan kekeliruan pribadi, maka kesalahan itu tidak mengganggu keadilan mereka, dan bila kesalahan pribadi tersebut telah menjadi kasus kedustaan yang mengatasnamakan Nabi Muhammad maka keadilan sahabat tersebut patut dipertanyakan.

\section{Jumlah sahabat periwayat hadis dan jumlah Hadis yang diriwayatkannya}

Mengetahui jumlah keseluruhan dari sahabat adalah sesuatu yang sulit sekali, karena mereka terpisah di daerah-daerah yang berbeda. AlBukhari meriwayatkan dalam kitab Shahihnya bahwa Ka'ab bin Malik mengatakan tentang cerita para sahabat yang tersisa dari perang Tabuk $^{30}$ : (وأصحاب رسول الله صلى الله عليه وسلم كثير، لايجمعهم كتاب حافظ) (Dan para sahabat Nabi SAW sangatlah banyak, dan nama-nama mereka semua tidak ada yang terkumpul dalam satu kitab". Dan mungkin bagi mengetahui jumlah mereka dari apa-apa yang diriwayatkan beberapa sahabat dan tabi în.

\footnotetext{
${ }^{30}$ Perang yang dipimpin oleh Nabi Muhammad Saw pada tahun $9 \mathrm{H}$, di daerah Tabuk.
} 


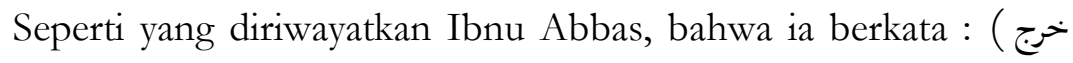
رسول الله صلى الله عليه وسلم لعشر مضين من رمضان فصام وصام الناس معه، حتى إذا كانو 131, dan juga ketika seseorang bertanya kepada Abu Zar'ah al-Razi, maka berkatalah ia يا أبا زرعة، أليس يقال حديث النبى أربعة آلاف حديث؟ حال : ومن قال ذا؟ هذا قول ) : الزنادقة، ومن يكصى حديث رسول الله صلى الله عليه وسلم؟ قبض رسول الله صلى اللى الله عليه

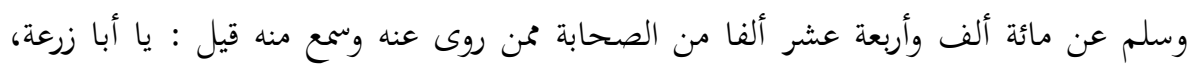

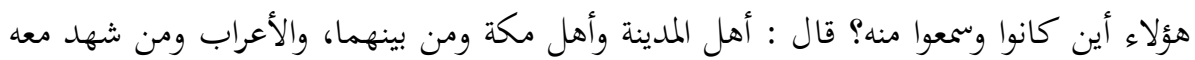
)

Dari sini dapat dijelaskan bahwa sahabat yang meriwayatkan Hadis dari Rasulullah Saw sangatlah banyak, perbedaan mereka ada pada jumlah Hadis yang diriwayatkannya, karena mereka juga berbeda dalam al-sbubbab dengan Nabi.

'Ajijaj al-Khatīb menyebutkan dalam kitabnya Úšil al-Hadis, sahabat yang paling banyak meriwayatkan Hadis dari Rasulullah Saw ada tujuh :

1. Abu Hurairah, nama lengkapnya Abdurrahman bin shakr alDausiy. Lahir pada tahun 19 sebelum Hijrah, meninggal pada tahun $59 \mathrm{H}$. dan jumlah hadis yang diriwayatkannya 5374 Hadis.

2. Abdullah bin 'Umar bin Khattab. Lahir pada tahun 10 sebelum Hijrah, dan meninggal pada tahun $73 \mathrm{H}$. jumlah hadis yang diriwayatkannya 2630 Hadis.

3. Anas bin Malik, lahir pada tahun 10 sebelum Hijrah, dan meninggal pada tahun $93 \mathrm{H}$. dan jumlah hadis yang diriwayatkannya 2286 Hadis.

4. 'Aisyah binti Abi Bakr al-Shiddiq, ummu al-mukminin, lahir pada tahun 9 sebelum Hijrah, dan meninggal pada tahun $58 \mathrm{H}$. Hadis yang diriwayatkannya berjumlah 2210 Hadis.

5. 'Abdullah bin 'Abbas bin Abdu al-Muthallib, lahir pada tahun 3 sebelum Hijrah, dan meninggal pada tahun $68 \mathrm{H}$. Hadis yang diriwatkannya berjumlah 1660 Hadis.

6. Jabir bin 'Abdullah al-Anshariy, lahir pada tahun 6 sebelum Hijrah, dan meninggal pada tahun $78 \mathrm{H}$. hadis yang diriwayatkannya berjumlah 1540 Hadis.

\footnotetext{
${ }^{31}$ H.R.Bukhari.

32 'Ajjaj al-khotīb, Ușül al-Hadis 'Ulümubu wa Mustolābubu (Dar al-fikr, Beirut : 2008)hal. 266.
} 
7. Abu Sa'id al-Khudriy, nama lengkapnya Sa'id bin Malik bin Sinan al-Anshariy, lahir pada tahun 12 sebelum Hijrah, dan meninggal pada tahun $74 \mathrm{H}$. Hadis yang diriwayatkannya berjumlah 1170 Hadis ${ }^{33}$.

\section{Penutup}

Dari pemaparan diatas dapat disumpulkan bahwa sahabat adalah orang yang berkedudukan mulia dan bermartabat tinggi, dimana secara makna bahasa atau istilah yang telah disepakati para ulama itu berarti mencakup seluruh muslim yang sezaman dengan Rasulullah saw. Artinya, mereka adalah sahabat, yaitu karena : pertama, pernah bertemu dengan Rasululla saw. Kedua, beriman dengan sebenarnya ; juga mencakup orangorang ynag hanya menampakkan keimanan pada Nabi saw masih hidup saja, seperti orang-orang munafik, dan orang-orang yang pernah memerangi Islam tetapi kemudian terpaksa memeluk Islam karena kekuasaan telah berada ditangan umat Islam. Hanya Allah yang mengetahui segala niat mereka; dan ketiga, Orang-orang yang meninggal dalam keadaan Islam.

Bagaimanapun juga para sahabat adalah para penukil syariat langsung dari Rasulullah Saw mupun dari sahabat lain, dibenak merekalah al-Qur'an dan Hadis ditulis dan dihafal, maka ketetapan keadilan seluruh sahabat adalah tentu bukan tanpa alasan, karena itu sangat penting dan dibutuhkan, karena merekalah yang secara langsung mendengar syari'at dari rasulullah Saw, apabila kita meragukan keadilan mereka, maka secara tidak langsung kita mematikan sumber-sumber syari'at agama, dari sisi lain kita telah mendustakan ayat-ayat al-Qur'an dan Hadis yang menetapkan keadilan bagi mereka.

33 'Ajjaj al-Khotib, Ușū al-Hadis 'Ulümubu wa Mustolāhubu (Dar al-fikr, Beirut : 2008)hal.267-268. 


\section{DAFTAR PUSTAKA}

al-Asqālani, Ibn Hajar. Al-Ișābah fi Tamyìzi al-Ṣāhabah, Jilid 1. Darr alkutub al-Azhar, Mesir: 1853.

al-Khoțib, 'Ajjaj. al-Sunnah Qobla al-Tadwīn, ummu al-quro, Kairo : 1988.

al-Khoțib, 'Ajjaj. Ușūl al-Hadìs Ulümubu wa Mustolābubu, Dar al-fikr, Beirut : 2008

at-Ṭahan, Mahmūd. Taysīru Mustalāhi al-Hadis, Markaz al-Hadyi li alDirasat, Iskandariah : $1415 \mathrm{H}$.

al-Rāzy, Asrāru al-Tan₹̄ill, Darr al-Fikr, Beirut : tth.

al-Jawwābi,Muhammad Ṭōhir. Al-jarh wa al-ta'dīl baina al-mutashaddidīn wa al-mutasabilin, Ad-dar al-'arabiyah : 1997.

Mustafa al-Siba'I, Al-Sunnah Wa Makēnatubā Fi Al-Tasyrì' Al-Islämi, alMaktab al-Islāmiy, Kairo, 2000.

Mustafa al-A'dhāmi, Dirasāt fi al-Hadis al-Nabawì wa Tarikhi Tadwinibi, al-

Maktab al-Islāmi, Beirut, 1980.

al-Thabrani, Mu'jam al-Kabir, juz XX, tth. ,Mu'jam al-Awsat, juz V, tth.

al-Razzaq, Abd. Mushannif, juz XI, th.

Al-Suyuthi, Durr al-Mantsur, Jilid V, th.

Al-Bukhariy, Tafsir Surah Hud ayat 114

Hamzah, Ibn. al-Bayan wa al-Ta'rif fi Asbab al-Nuzul al-Hadits al-Syarif, Jilid I, Mesir: Maktabah al-Mishr, 1985

Al-Thabrani, Ibn Atsir, Usud al-Ghabah, jilid I, tth.

Abu Dawud, Sunan Abu Dawud, kitab al-thaharah, hadis no. 266, Jilid I, ttp. tth.

Al-Darimiy, Sunan al-Darimiy, kitab al-thaharah, hadis no. 1090, jilid I ttp. Tth. 